University of Wollongong

Research Online

Faculty of Engineering and Information

Faculty of Engineering and Information

Sciences - Papers: Part A

Sciences

$1-1-2013$

Shear lag and eccentricity effects of bolted connections in cold-formed steel sections

Lip H. Teh

University of Wollongong, Iteh@uow.edu.au

Veysel Yazici

University of Wollongong, veysel@uow.edu.au

Follow this and additional works at: https://ro.uow.edu.au/eispapers

Part of the Engineering Commons, and the Science and Technology Studies Commons

Research Online is the open access institutional repository for the University of Wollongong. For further information contact the UOW Library: research-pubs@uow.edu.au 


\title{
Shear lag and eccentricity effects of bolted connections in cold-formed steel sections
}

\begin{abstract}
This paper examines the "three factors" approach previously presented by the senior author for determining the net section efficiency of a bolted cold-formed steel open profile. One objective is to ascertain that the net section efficiency is governed by three factors: the in-plane shear lag associated with stress concentration around a bolt hole that is also present in a flat sheet, the out-of-plane shear lag that is also present in a bi-symmetric l-section bolted at the flanges only, and the bending moment arising from the connection eccentricity with respect to the neutral axis. This paper presents the test results of 55 single and back-to-back channel braces bolted at the web including those connected with one row of bolts perpendicular to the axial load. The test results affirm the three factors approach, and it was found that the back-to-back channel braces were affected by local bending even though the connection eccentricity was nominally zero. The paper asserts the need to avoid snug-tightening laboratory test specimens and the importance of identifying the failure modes accurately.
\end{abstract}

\section{Keywords}

formed, cold, connections, bolted, effects, eccentricity, lag, sections, shear, steel

\section{Disciplines}

Engineering | Science and Technology Studies

\section{Publication Details}

Teh, L. H. \& Yazici, V. (2013). Shear lag and eccentricity effects of bolted connections in cold-formed steel sections. Engineering Structures, 52 536-544. 
1 Shear Lag and Eccentricity Effects of Bolted Connections in Cold-Formed (1)

\title{
Steel Sections
}

\author{
Lip H. Teh ${ }^{\mathrm{a}^{*}}$, Veysel Yazici ${ }^{\mathrm{b}}$
}

${ }^{a}$ Senior Lecturer, School of Civil, Mining \& Environmental Engineering, University of Wollongong, Wollongong, NSW 2522, Australia.

${ }^{\mathrm{b}}$ Research Assistant, School of Civil, Mining \& Environmental Engineering, University of Wollongong, Wollongong, NSW 2522, Australia.

${ }^{*}$ Corresponding author at School of Civil, Mining \& Environmental Engineering, University of Wollongong, Wollongong, NSW 2522, Australia. Tel: +61242213564, fax: +61242213238, e-mail: $\underline{\text { lteh@uow.edu.au }}$

\section{Introduction}

The net section tension capacity of a bolted steel profile such as a channel or an angle cannot be computed simply as the product of its net section area and its material tensile strength, which would otherwise imply a full net section efficiency. In reality, the net section efficiency is invariably less than unity due to a number of factors [1-5]. In order to account for the reduced net section efficiency of bolted steel profiles, constant reduction factors [6] and simple formulae [7- 8] have been incorporated into the code equations for determining the net section tension capacity. Regression analysis of laboratory test results is also popular in the literature [3-4, 9-13].

The equations specified in the design standards [6-8], mainly based on the work of Munse \& Chesson [2], have been found to be unconservative for most specimens [3-5, 10-11, 14-15]. Equations derived using regression analysis, on the other hand, have been shown by Teh \& Gilbert $[5,16]$ to have pitfalls if not handled properly.

Recently, Teh \& Gilbert [5] proposed a design equation for determining the net section tension capacity of a channel brace bolted at the web. The equation incorporates the in-plane 
shear lag associated with stress concentration around a bolt hole that is also present in a flat sheet, the out-of-plane shear lag that is also present in a bi-symmetric I-section bolted at the flanges only, and the bending moment arising from the connection eccentricity with respect to the neutral axis. It was shown through laboratory tests that the equation is significantly more accurate and reliable than the code equations and those derived in the literature using regression analysis.

The equation proposed by Teh \& Gilbert [5] for a channel brace bolted at the web was modified by Teh \& Gilbert [14] to suit an angle brace bolted at one leg. While the modified equation was shown to be accurate except for unequal angles bolted at the narrow leg, it was noted that a single angle brace bolted at one leg is subject to biaxial bending under the axial load. Furthermore, the net section efficiency of double angles, which were subject to bending in the symmetry plane only, was not found to be higher than that of single angles.

It is significant that the term $\bar{x} / L$ contained in the efficiency factor expression, considered by Teh \& Gilbert $[5,14]$ to represent the interaction between the detrimental bending moment due to connection eccentricity $\bar{x}$ and the counteracting moment provided by the bolt couple acting at $L$ distance apart, was considered by Munse \& Chesson [2] to account for the out-ofplane shear lag. In the formulation of Teh \& Gilbert $[5,14]$, the latter effect is a function of the ratio of the unconnected element width to the total element width only.

The AISC specification for structural steel buildings [7] determines the net section efficiency factor of a bolted profile to be the larger of the two values computed as a function of $\bar{x} / L$ and as the ratio of the connected element width to the total element width. Teh \& Gilbert [5, 14], on the other hand, treats the two factors as cumulative. The AISC approach [7] means that, in theory, two sections having the same ratio may be found to have the same net section efficiency even if their connection eccentricities differ from each other. 
50 The present work aims to ascertain that the net section efficiency of a bolted cold-formed steel open profile is governed by the three factors described by Teh \& Gilbert [5]. The equation proposed by Teh \& Gilbert [5] is verified against the laboratory test results of double channel braces bolted symmetrically back-to-back, for which the connection eccentricity $\bar{x}$ is nominally zero.

This paper also presents the test results of single channels connected at the web with a single line or row of bolts parallel or perpendicular to the axial load, complementing the tests of Teh \& Gilbert [5] on single channels bolted in a rectangular pattern. In addition, the present aspect ratios are as high as 0.6. An aspect ratio is the ratio of the flange width to the web depth. The proposed equation was also verified against the test results of Pan [10] involving an aspect ratio as high as 0.75 .

The paper includes some discussions on the needs to ensure that laboratory test specimens are not snug-tightened, and to accurately identify the actual failure mode of bolted connection specimens.

\section{Equations for the net section tension capacity of a channel brace}

Clause 3.2.2(3) of AS/NZS 4600:2005 Cold-formed Steel Structures [6] specifies the net section tension capacity of a bolted connection in a steel member to be

$$
P_{p}=0.85 k_{t} A_{n} F_{u}
$$
in which $A_{\mathrm{n}}$ is the net area of the section and $F_{\mathrm{u}}$ is the material tensile strength of the member. The variable $k_{\mathrm{t}}$ in the equation represents the net section efficiency factor, which is equal to unity for a connection that ensures uniform stress distribution over the net section. 
71 The clause is adopted from AS 4100-1998 Steel Structures [17]. The explicit coefficient of 0.85 embedded into Equation (1) "is intended to account for sudden failure by local brittle behaviour at the net section" [18] and is therefore in a sense part of the resistance factor. The reason for the sudden brittle failure not being accounted for using a lower (formal) resistance factor is that a uniform resistance factor of 0.90 is applied to the net section fracture mode and the member yielding (over the gross section) mode under axial tension. The effective resistance factor actually applied to the net section fracture mode is therefore 0.765 .

For the purpose of the present work, the explicit coefficient of 0.85 in Equation (1) is ignored since it is actually part of a safety factor rather than a net section efficiency factor. In accordance with Table 3.2 of the Australasian code [6], which specifies the values of $k_{\mathrm{t}}$ for various connection arrangements, Equation (1) is replaced by

$$
P_{p}=A_{n} F_{u}
$$

83 for a double channel brace symmetrically bolted back-to-back $\left(k_{\mathrm{t}}=1.0\right)$, and

$$
P_{p}=0.85 A_{n} F_{u}
$$

85 for a single channel brace bolted at the web $\left(k_{\mathrm{t}}=0.85\right)$.

86 Section E5.2 of Supplement No. 2 to the North American Specification for the Design of

87 Cold-formed Steel Structural Members 2007 [8] specifies the net section tension capacity of a channel brace bolted at the web to be

$$
P_{p}=A_{n} F_{u} \max \left\{0.5, \min \left(0.9,1-0.36^{\bar{x}} / L\right)\right\}
$$
in which $\bar{x}$ is the distance between the web's outer face and the section's neutral axis (i.e. the connection eccentricity), and $L$ is the connection length. These variables are defined in Figure 
92 1. It will be seen that, for most practical channel connections, Equation (4) gives a net section efficiency factor equal to 0.9 , which is over-optimistic for most channel sections.

94 The function "max" in Equation (4) means that the larger between the two values inside the outer brackets is to be used, while the function "min" means that the lesser between the two

96 values inside the inner brackets is to be used.

97 Equation (4) was proposed by LaBoube \& Yu [19] based on the laboratory test results of 98 Holcomb et al. [12] and the original equation proposed by Munse \& Chesson [2] to account 99 for "shear lag" in a steel member where not all of its cross-sectional elements are bolted to 100 the joining member. The original equation is still used in the current AISC specification [7] 101 with a lower bound "shear lag factor" equal to the ratio of the connected width to the total 102 width

$$
P_{p}=A_{n} F_{u} \max \left(1-\bar{x} / L, \frac{W_{c}}{W_{c}+2 W_{f}}\right)
$$

104 in which $W_{\mathrm{c}}$ is the web depth and $W_{\mathrm{f}}$ is the flange width as defined in Figure 1. In practically 105 all cases, the lower bound does not affect the outcome of Equation (5).

106 Teh \& Gilbert [5] proposed the following equation for determining the net section tension 107 capacity of a single channel brace bolted at the web

108

$$
P_{p}=A_{n} F_{u}\left(\frac{1}{1.1+\frac{W_{f}}{W_{c}+2 W_{f}}+\frac{\bar{x}}{L}}\right)
$$

109 As explained by Teh \& Gilbert [5], the constant of 1.1 in the denominator of Equation (6) 110 accounts for the in-plane shear lag effect present in the steel sheet [16], the term $W_{\mathrm{f}} /\left(W_{\mathrm{c}}+\right.$ 
$\left.1112 W_{\mathrm{f}}\right)$ accounts for the out-of-plane shear lag effect of a channel brace bolted at the web, and

112 the term $\bar{x} / L$ accounts for the detrimental bending moment effect due to the connection

113 eccentricity $\bar{x}$ and for the counteracting bending moment effect that increases with the

114 connection length $L$. It can be seen from the statistical analysis of test results found in the

115 literature conducted by Pan [10] that the out-of-plane shear lag and the eccentricity terms are

116 independent variables.

117 Since the term $\bar{x} / L$ was intended by Munse \& Chesson [2] to account for the out-of-plane

118 shear lag effect, for a double channel brace bolted symmetrically back-to-back, this term

119 vanishes only in the approach of Teh \& Gilbert [5]. Equation (6) becomes, for such a brace

120 not subject to bending under the axial load

$$
P_{p}=A_{n} F_{u}\left(\frac{1}{1.1+\frac{W_{f}}{W_{c}+2 W_{f}}}\right)
$$

\section{3. Test materials}

124 The G450 sheet steel materials used in the laboratory tests, which have a trade name

125 GALVASPAN $^{\circledR}$, were manufactured and supplied by Bluescope Steel Port Kembla

126 Steelworks, Australia. Two nominal thicknesses were used in the present work, being $1.5 \mathrm{~mm}$

127 and $3.0 \mathrm{~mm}$. The average base metal thicknesses $t_{\text {base }}$, yield stresses $F_{y}$, tensile strengths $F_{u}$

128 and elongations at fracture over $15 \mathrm{~mm}, 25 \mathrm{~mm}$ and $50 \mathrm{~mm}$ gauge lengths $\varepsilon_{15}, \varepsilon_{25}$ and $\varepsilon_{50}$, and

129 uniform elongation outside the fracture $\varepsilon_{\text {uо }}$ of the steel materials as obtained from six 12.5

$130 \mathrm{~mm}$ wide tension coupons are shown in Table 1. Tensile loadings of all coupons and bolted 
connection specimens are in the direction perpendicular to the rolling direction of the G450 sheet steel. The tension coupon tests were conducted at a constant stroke rate of $1 \mathrm{~mm} / \mathrm{minute}$ resulting in a strain rate of about $2 \times 10^{-4}$ per second prior to necking.

134 The tensile strengths in the direction perpendicular to the rolling direction of $1.5 \mathrm{~mm}$ and 3.0 $135 \mathrm{~mm} \mathrm{G} 450$ sheet steels obtained in the present work, rounded to the nearest $5 \mathrm{MPa}$, are $6 \%$ 136 and $10 \%$ higher than those obtained by Teh \& Hancock [20] in the rolling direction. While

137 Teh \& Hancock [20] did not provide the elongations at fracture, it is believed that the rolling 138 direction is associated with higher ductility. In any case, the G450 sheet steels used in the 139 present work represent the grades of steel covered by AS/NZS 4600 [6] which are among 140 those having the lowest ductility and for which the nominal tensile strength and yield stress may be fully utilised in structural design calculations [21]. The use of such low ductility steel ensures that the proposed design equation is not unsafe for more ductile steels.

143 The sheet steels were brake-pressed into channel sections, with the 1.5-mm sections having a 144 corner radius of $2 \mathrm{~mm}$ and the $3.0-\mathrm{mm}$ ones having a corner radius of $3 \mathrm{~mm}$.

\section{4. Specimen configurations and test arrangements}

146 The back-to-back double channel specimens comprise sections having web depths of 80, 100

147 and $120 \mathrm{~mm}$, with flange widths ranging from 20 to $50 \mathrm{~mm}$, corresponding to the dimensions

148 of the single channel specimens tested by Teh \& Gilbert [5]. Such an arrangement enables the 149 investigation of the significance of the term $\bar{x} / L$ found in Equation (6).

150 As with the single specimens tested by Teh \& Gilbert [5], the back-to-back channel 151 specimens had two rows of bolts arraigned in a rectangular pattern, as depicted in Figure 1.

152 However, the present work includes single channel specimens having a single line of bolts in 
153 the direction of loading, as shown in Figure 2, to complement the single specimens of Teh \&

154 Gilbert [5]. The highest aspect ratio of the present single specimens is 0.6, composed of a

155 channel section having a web depth of $50 \mathrm{~mm}$ and a flange width of $30 \mathrm{~mm}$.

156 The bolts at the downstream ends (i.e. those closest to the member ends) were tightened as

157 snug as possible with a wrench to prevent "global bending" of the back-to-back specimens,

158 associated with the separation of the webs from the gusset plates. However, in order to ensure

159 that friction did not contribute to the tension capacity, the bolts at the upstream end were only

160 lightly tightened. As illustrated in Figure 3, only friction of the bolts at the upstream end

161 would contribute to the tension capacity of the critical net section since the resultant of

162 stresses at the critical section A-A resisting the tension load $P$ does not include the friction of

163 the downstream bolts. As will be discussed later, friction between the gusset plates (or the

164 washer) and the bolted specimen is an important factor that has often been overlooked in the

165 literature.

166 As demonstrated by Teh \& Gilbert [5], channel braces bolted at the web that have a single

167 row of bolts only perpendicular to the axial load tend to fail in either block shear or bearing,

168 even for a channel section with an aspect ratio of 0.2. In order to obtain net section fracture,

169 the aspect ratio has to be as low as 0.1 , resulting in minimal eccentricity $\bar{x}$ as seen later. The

170 possibility of applying Equation (7) to such connections was investigated.

171 The bolted connection specimens were tested to failure using an Instron 8033 universal

172 testing machine at a stroke rate of $1 \mathrm{~mm} /$ minute. The test set-up is shown in Figure 4. 


\section{Experimental test results and discussions}

175 In calculating the net section tension capacity $P_{\mathrm{p}}$ of a specimen, the measured values of the

176 material properties and geometric dimensions such as the base metal thickness, the web

177 depth, the flange width, the bolt hole diameter and the connection length, are used. However,

178 for legibility, only the nominal values are shown in the tables following.

179 Only the code equations [6-8] and the equations proposed by the authors are discussed in this

180 section. Equations proposed in the literature for determining the net section tension capacity

181 of a channel brace $[10,12]$ have been previously discussed by Teh \& Gilbert [5].

\section{5.1. Double channel sections bolted back-to-back}

183 Table 2 lists the relevant geometric dimensions and the test results of the back-to-back double

184 channel specimens. An empty cell in the table indicates that the data in the above cell applies.

185 The variable $c$ denotes the actual net section efficiency factor, defined as the ratio of ultimate

186 test load $P_{\mathrm{t}}$ to net section tension capacity $P_{\mathrm{p}}$ computed with the assumption of uniform stress

187 distribution

188

$$
c=\frac{P_{t}}{A_{n} F_{u}}
$$

189 All specimens failed in net section fracture, as shown in Figure 5 for CB7.

190 Table 2 shows the ratios of the ultimate test load $P_{\mathrm{t}}$ to the net section tension capacity $P_{\mathrm{p}}$

191 predicted by Equations (2) and (4) through (7). In applying Equations (4) through (6), the

192 connection eccentricity $\bar{x}$ of the individual channel has been used. 
193 It can be seen from the actual net section efficiency factors $c$ in Table 2 that the assumption of

194 uniform stress distribution in Equation (2) is unjustified. On the other hand, despite the use of

195 the individual channel's eccentricity $\bar{x}$ to account for the out-of-plane shear lag effect,

196 Equations (4) and (5) still lead to overestimations. In particular, Equation (4) suggests a net

197 section efficiency factor equal to the upper bound value of 0.9 for all specimens except for

198 CB10 since the term " $1-0.36 \bar{x} / L$ " is greater than 0.9 for these specimens.

199 Equation (7) results in an average professional factor equal to 0.98, with a standard variation

200 of 0.084 . Table 2 shows that Equation (7) fails to account for the effects of connection

201 eccentricity and connection length. Although the eccentricity $\bar{x}$ is nominally zero, the back-

202 to-back double channel specimens were subjected to significant local bending, as shown in

203 Figure 6(a). There were therefore detrimental local bending effects, as well as counteracting

204 bending effects from the bolt couples acting at $L$ distance apart.

205 Equation (6) leads to the most reasonable if conservative estimates for the back-to-back

206 double channel specimens. The use of the individual channel's eccentricity $\bar{x}$ (more than)

207 captures the local bending phenomena shown in Figure 6(a), which can be compared to the

208 global bending of the single channel specimen shown in Figure 6(b).

209 As indicated in Table 2, specimen CB12 had three rows of bolts in order to prevent bolt shear

210 failure. Based on the rationale of Teh \& Gilbert [5], who derived Equation (6), the number of

211 bolt rows is irrelevant to the net section efficiency. This rationale is supported by the

212 laboratory test results of Salih et al. [13] on angle braces bolted at one leg.

213 It is also evident from the results of Equation (7), which does not account for local or global

214 bending, that the St Venant's effect of the downstream bolts on the stress distribution at the

215 critical net section was significant. For 100-mm long connections, the St Venant's effect more 
216 than offset the absence of connection eccentricity $\bar{x}$ in the equation such that the equation

217 was found to be conservative for most of these specimens.

\section{5.2. Single channels connected at the web with a single line of bolts}

219 Table 3 lists the relevant geometric dimensions and the test results of the single channel 220 specimens with a single line of bolts in the axial direction. An empty cell in the table 221 indicates that the data in the above cell applies. The table shows the ratios of the ultimate test 222 load $P_{\mathrm{t}}$ to the net section tension capacity $P_{\mathrm{p}}$ predicted by Equations (3) through (6). All the specimens failed in the net section fracture mode, as shown in Figure 2 for 1.5 and $3.0 \mathrm{~mm}$ specimens.

Equations (3) through (5) were found to be over-optimistic for the present single channel specimens with a single line of bolts, affirming the conclusion of Teh \& Gilbert [5], who tested single channel braces with the bolting pattern depicted in Figure 1.

It can be seen from Table 3 that Equation (6) is reasonably accurate for the present single channel specimens with a single line of bolts, although the resulting coefficient of variation is significantly greater than that for the single channel specimens with a rectangular bolting pattern tested by Teh \& Gilbert [5]. The latter is reproduced in Table 4.

\subsection{Single channels connected at the web with a single row of bolts}

Table 5 lists the geometric dimensions and the test results of the single channel specimens with a single row of bolts perpendicular to the axial load. An empty cell in the table indicates that the data in the above cell applies. The aspect ratio of these specimens, 0.1 , is extremely

236 low in order to obtain the net section fracture mode, as shown in Figure 7(a). In fact, there is 237 minimal eccentricity $\bar{x}$. 
238 As it transpired, the in-plane and out-of-plane shear lag terms in Equation (7) are sufficient to

239 accurately determine the net section efficiency factors of the tested specimens.

\section{5.4. Frictional forces between gusset plates and bolted specimen}

241 An instructive set of test results were provided by Yip \& Cheng [22], who tested single

242 channel braces connected at the web with a single line of bolts in the axial direction, similar

243 to the CSS specimens shown in Figure 2. Five of their specimens failed in net section

244 fracture. The test net section efficiency factors of all these specimens were found to be higher

245 than unity, with a median of 1.14.

246 Such test results are "anomalous" since the net section efficiency factor of a bolted channel

247 brace cannot be greater than unity. The strain measurement results indicate compression

248 stresses in the flanges [22], meaning the net section efficiency must be low.

249 Yip \& Cheng [22] found that the ultimate test loads of the five specimens were significantly

250 higher than their finite element predictions, with a maximum over-strength of more than $30 \%$.

251 They suggested that the discrepancies were due to the neglect of frictional forces between the

252 gusset plates and the bolted specimens in their finite element models. In this regard, good

253 agreements between laboratory test results and FEA predictions were obtained by Salih et al.

254 [13], who modelled the friction between contact surfaces of their bolted connections.

255 After pre-loading a specimen so that the bolts bore against the gusset plates and the specimen,

256 Yip \& Cheng [22] snug-tightened the bolts. This procedure means that the frictional forces

257 between the gusset plates and the bolted specimen contributed to the apparent net section

258 tension capacity (even though the load reading was returned to zero following the pre-load). 
259 Since the first paper in the series on the subject was written by the senior author [16], a point

260 is made that the bolts were not tightened to the extent that the frictional forces contributed

261 significantly to the net section tension or block shear capacity, as also made in the section

262 "Specimen configurations and test arrangements". Rogers \& Hancock [23] tightened the bolts

263 by hand to a torque less than $10 \mathrm{Nm}$ to ensure that the connection was able to slip under

264 minimal loading. However, in the literature of cold-formed steel bolted connections, a torque

265 of at least $100 \mathrm{Nm}$ has been applied [11].

266 The provision in steel design specifications that bolts must be installed to a snug tight level

267 should not be a cause to ignore potentially significant frictional forces in an experiment. It is

268 prudent to prevent frictional forces from contributing to the net section tension or block shear

269 capacity of a test specimen, if only to avoid anomalous test results and incorrect conclusions.

270 As an aside, Yip \& Cheng [22] and Chung \& Ip [24, 25] have found that the friction between

271 the interfaces of a bolted connection contributes significantly to the bearing resistance too.

\section{$272 \quad$ 5.5. Net section fracture or block shear failure?}

273 Pan [10] tested single channel braces bolted at the web with the rectangular pattern depicted in Figure 1. Some of the specimens had the same web and flange dimensions as the $\mathrm{CH}$ specimens listed in Table 4. The SSC400 sheet steel used by Pan [10] was however significantly more ductile than the G450 sheet steel used by Teh \& Gilbert [5].

277 Table 6 lists the relevant geometric dimensions and the results of Group A specimens tested

278 by Pan [10]. An empty cell in the table indicates that the data in the above cell applies. The variable $W_{\mathrm{T}}$ is the total nominal sheet width, equal to $W_{\mathrm{c}}+2 W_{\mathrm{f}}$. The measured tensile strength of the material is $450 \mathrm{MPa}$ (rounded to the nearest $5 \mathrm{MPa}$ from the reported 447.77 $\mathrm{MPa}$ ). The base metal thickness was assumed to be $2.4 \mathrm{~mm}$ in the calculations since it was 
not reported. The nominal bolt hole diameter of $14.3 \mathrm{~mm}$ was also used in the calculations. In determining the connection eccentricity $\bar{x}$, a corner radius of $2.5 \mathrm{~mm}$ was assumed in the computer program ColdSteel [26]. Each of the test results in Table 6 is the average of three specimens having the same nominal configuration, except for the last entry in which case it is the average of two $120 \mathrm{~mm}$ by $40 \mathrm{~mm}$ specimens only.

Equation (6) results in reasonably accurate estimates for the specimens having a web depth $W_{\mathrm{c}}$ of $80 \mathrm{~mm}$, with aspect ratios ranging from 0.5 to 0.75 . However, the results of the deeper specimens are not so encouraging. A close examination of the test results of the $100-\mathrm{mm}$ and 120-mm deep specimens revealed that they were likely to have been in error.

291 The test results would indicate that the net section efficiency factors $c$ decreased with 292 decreasing aspect ratios for a constant flange width $W_{\mathrm{f}}$ of $40 \mathrm{~mm}$, as shown in Table 6 . 293 However, the reverse should be true provided the failure modes were all net section fracture. 294 As demonstrated by Teh \& Gilbert [5], for a constant flange width $W_{\mathrm{f}}$ of $40 \mathrm{~mm}$, the net section efficiency should increase with increasing web depths from $80 \mathrm{~mm}$ to $120 \mathrm{~mm}$ as the aspect ratios decrease. The reason is that the out-of-plane shear lag effect and the connection eccentricity $\bar{x}$ decrease over this variation.

The eagle-eyed reader may also notice the incidental "symmetry" of the test net section

299 efficiency factors $c$ in Table 6 about the middle specimen, which would imply that the channel braces having the same total width $W_{\mathrm{T}}$ had the same net section tension capacity irrespective of their aspect ratios (ranging from 0.33 to 0.75 ). Furthermore, the test net section efficiency factors in Table 6 could be approximated as $k / W_{\mathrm{T}}$, with the constant $k$ equal to $106(\mathrm{~mm})$. Such a direct inverse relationship is highly unlikely as it does not account for the effects of out-of-plane shear lag and connection eccentricity. It is even unlikely for bolted connections in flat sheets [16]. 
306 One possible explanation for the "anomaly" of the test results of the $100-\mathrm{mm}$ and $120-\mathrm{mm}$

307 deep specimens is that a failure mode other than net section fracture was involved.

308 Sometimes a block shear failure, an example of which is shown in Figure 7(b), could be

309 mistaken for a net section fracture mode, an example of which is shown in Figure 7(a). The

310 reason why the specimen in Figure 7(b) is considered to fail in block shear can be found in

311 Teh \& Clements [27], while the reason why it was not bearing can be found in Clements \&

312 Teh [28]. The likelihood of block shear failure increases with increasing web depths,

313 especially if the bolt spacing in the transverse direction to loading does not increase

314 commensurately.

315 Misidentifications of failure modes in the literature of cold-formed steel bolted connections

316 have been documented by Rogers \& Hancock [29], who also described the methodology for

317 identifying various failure modes (other than block shear failure).

318 5.6. Resistance factor (or capacity reduction factor)

319 For the sake of simplicity, it is intended that a uniform resistance factor is applied to Equation

320 (6) for single and double channel braces connected at the web (whether symmetrically or

321 not). However, in order to prevent the results of the double channel specimens bolted

322 symmetrically back-to-back from skewing the resistance factor higher, these specimens were

323 not included in the determination of the resistance factor. The overall average ratio of the

324 ultimate test load $P_{\mathrm{t}}$ to the net section tension capacity $P_{\mathrm{p}}$ predicted by Equation (6) for the

325 forty one CSS and CH specimens listed in Tables 3 and 4 is 1.01, with a standard deviation of 3260.064.

327 Section F1.1 of the North American specification [30] specifies that the resistance factor $\phi$ of 328 a design equation is determined as follows 


$$
\phi=C_{\phi}\left(M_{m} F_{m} P_{m}\right) e^{p}
$$

in which $C_{\phi}$ is the calibration coefficient equal to 1.52 in the case of the Load and Resistance

331 Factor Design (LRFD), $M_{\mathrm{m}}$ is the mean value of the material factor equal to 1.10 according to

332 Table F1 of the North American specification [30], $F_{\mathrm{m}}$ is the mean value of the fabrication

333 factor equal to 1.00 , and $P_{\mathrm{m}}$ is the mean value of the professional factor equal to 1.01 as stated in the preceding paragraph.

The power $p$ of the natural logarithmic base $e$ in Equation (9) is

$$
p=-\beta_{0} \sqrt{V_{M}^{2}+V_{F}^{2}+C_{p} V_{P}^{2}+V_{Q}^{2}}
$$

in which $V_{\mathrm{M}}$ is the coefficient of variation of the material factor equal to $0.08, V_{\mathrm{F}}$ is the coefficient of variation of the fabrication factor equal to $0.05, V_{\mathrm{P}}$ is the coefficient of variation of the professional factor equal to $0.065, C_{\mathrm{p}}$ is the correction factor equal to 1.08 , and $V_{\mathrm{Q}}$ is the coefficient of variation of load effects equal to 0.21 . All these values are determined in accordance with Section F1.1 of the North American specification [30].

It was found that in order to achieve the target reliability index $\beta_{0}$ of 3.5 in the LRFD,

343 Equation (9) yields a resistance factor of 0.73.

344 A resistance factor $\phi$ equal to 0.70 (rounded down to the nearest 0.05 ) in conjunction with

345 Equation (6) is therefore recommended for the LRFD approach for determining the net 346 section tension capacity of a cold-formed steel channel brace bolted at the web only, whether 347 single or double (symmetrically or un-symmetrically connected back-to-back). This value 348 would be the same as that found by Teh \& Gilbert [5] for the $\mathrm{CH}$ specimens in Table 4 if the statistical variables recommended in Table F1.1 of the North American specification [30] are used in the calculation, and is higher than the current value of 0.65 used in the specification. 
351 Only two channel brace specimens with a single row of bolts perpendicular to the axial load were tested to net section fracture, and no reliability analysis has been used to determine the resistance factor to be applied to Equation (7). However, considering that only channel braces with extremely low aspect ratios will fail in net section fracture when connected with a single row of bolts, it appears from the results shown in Table 5 that it is reasonable to apply the same capacity factor of 0.7 to Equation (7) for such cases.

\section{Conclusions}

Laboratory test results of fifty five channel braces bolted at the web which failed in net section fracture have been presented in this paper. The single channel specimens were bolted with four bolts in a rectangular pattern, a single line of bolts in the axial direction, or a single row of bolts perpendicular to the axial load. The results affirm the design equations in which the net section efficiency of a bolted cold-formed steel open profile is reduced by three distinct factors: the in-plane shear lag associated with stress concentration around a bolt hole that is also present in flat sheets, the out-of-plane shear lag that is also present in a bisymmetric I-section bolted at the flanges only, and the bending moment arising from the connection eccentricity with respect to the neutral axis.

367 Even though the connection eccentricity of a double channel brace bolted symmetrically back-to-back is zero, local bending can reduce the net section efficiency significantly. It is

369 proposed that the same design equation is applied to single and double channel braces bolted 370 at the web so that the three factors are always accounted for.

371 A slightly modified equation, in which the bending effect is neglected, can be applied to

372 channel braces having a single row of bolts perpendicular to the axial load. If the aspect ratio 
373 is 0.1 or lower, then the net section fracture mode may govern the strength limit state.

374 Otherwise, the net section fracture mode is irrelevant to the channel brace.

375 One important aspect that has often been overlooked in the literature is the contribution of

376 frictional forces between the gusset plates and the bolted specimen to the apparent net section

377 tension or block shear capacity. Snug-tightening of bolts, while mandated in the construction

378 field, should not be used in experimental tests unless the contribution of the frictional forces

379 is being researched or otherwise accounted for. Neglect of this aspect has led to anomalous

380 results that significantly overstate the true capacities.

381 Provided that net section fracture is the governing failure mode, the net section efficiency of a

382 channel brace increases with decreasing aspect ratios for a given flange width or a given web

383 depth. Test results to the contrary may indicate a failure mode other than net section fracture.

384 It is recommended that a resistance factor of 0.70 be applied to the two equations proposed in

385 this paper in order to ensure a reliability index of not less than 3.5 in the LRFD approach of

386 the North American specification for the design of cold-formed steel structures.

\section{Acknowledgments}

This research project was funded by the University of Wollongong's URC Small Grants

390 scheme. The authors would like to thank Prof. Arul Jayachandran for his comments that

391 improve the clarity of the paper. The specimens were fabricated by Ritchie McLean and

392 tested with the assistance of Julian Frate, an honours thesis student. 


\section{References}

395 [1] Epstein HI, Aiuto CLD. Using moment and axial interaction equations to account for 396 moment and shear lag effects in tension members, Engineering Journal AISC, 2002; 39 $397 \quad$ (3): $91-99$.

[2] Munse WH, Chesson E. Riveted and bolted joints: Net section design, J. Struct. Div. (ASCE), 1963; 89 (ST1): 107-126.

[3] Orbison JG, Barth KE, Bartels PA. Net section rupture in tension members with connection eccentricity, J. Struct. Eng., 2002; 128 (9): 976-985.

[4] Prabha P, Jayachandran SA, Saravanan M, Marimuthu V. Prediction of the tensile capacity of cold-formed angles experiencing shear lag, Thin-Walled Structures, 2011; 49 (1): 1348-1358.

405

[5] Teh LH, Gilbert BP. Net section tension capacity of cold-reduced sheet steel channel braces bolted at the web, J. Struct. Eng., 2013; 139 (5).

[6] AS/NZS 4600-2005. Cold-formed steel structures, Standards Australia/Standards New Zealand, 2005.

[7] ANSI/AISC 360-10. Specification for structural steel buildings, American Institute of $410 \quad$ Steel Construction, 2010.

411 [8] AISI. Supplement No. 2 to the North American Specification for the Design of Coldformed Steel Structural Members 2007 Edition, American Iron and Steel Institute, 2010.

413 [9] Chong KP, Matlock RB. Light-gage steel bolted connections without washers, J. Struct. 414 Div. (ASCE), 1975; 101 (ST7): 1381-1391. 
415 [10] Pan CL. Prediction of the strength of bolted cold-formed channel sections in tension, $416 \quad$ Thin-Walled Structures, 2004; 42 (1): 1177-1198.

417 [11] Paula VF, Bezerra LM, Matias WT. Efficiency reduction due to shear lag on bolted cold418 formed steel angles, J. Construct. Steel. Res., 2008; 64 (1): 571-583.

419 [12] Holcomb RD, LaBoube RA, Yu WW. Tensile and bearing capacities of bolted 420 connections, Second Summary Report, Civil Engineering Study 95-1, Cold-Formed Steel 421 Series, Center for Cold-Formed Steel Structures Department of Civil Engineering, $422 \quad$ University of Missouri-Rolla, 1995.

423 [13] Salih EL, Gardner L, Nethercot DA. Numerical study of stainless steel gusset plate $424 \quad$ connections, Eng. Struct., 2013; 49: 448-464.

425 [14] Teh LH, Gilbert BP. Net section tension capacity of cold-reduced sheet steel angle braces 426 bolted at one leg, J. Struct. Eng., 2013; 139 (3): 328-337.

427 [15] Maiola CH, Malite M, Goncalves RM, Neto JM. Structural behaviour of bolted 428 connections in cold-formed steel members, emphasizing the shear lag effect, Proceedings of 16th Int. Specialty Conf. Cold-Formed Steel Structures, Orlando, FL, 2002: 697-708.

430 [16] Teh LH, Gilbert BP. Net section tension capacity of bolted connections in cold-reduced 431 steel sheets, J. Struct. Eng., 2012; 138 (3): 337-344.

432 [17] AS 4100-1998. Steel Structures, Standards Australia, 1998.

433 [18] AS 4100-1999. Steel structures-Commentary, Standards Australia, 1999.

434 [19] LaBoube RA, Yu WW. Additional design considerations for bolted connections, 435 Proceedings of 13th Int. Specialty Conf. Cold-Formed Steel Structures, St Louis, MO, $436 \quad 1996: 575-593$. 
437 [20] Teh LH, Hancock GJ. Strength of welded connections in G450 sheet steels, J. Struct. $438 \quad$ Eng., 2005; $131(9):$ 1561-1569.

439 [21] Hancock GJ. Design of Cold-Formed Steel Structures, 4th ed., Australian Steel Institute, $440 \quad$ Sydney, 2007.

441 [22] Yip ASM, Cheng JJR. Shear lag in bolted cold-formed steel angles and channels in 442 tension, Struct. Engrg. Report No. 233, University of Alberta Dept. Civ. \& Env. Engrg., 443 Edmonton, Canada, 2000.

444 [23] Rogers CA, Hancock GJ. Bolted connection tests of thin G550 and G300 sheet steels, J. $445 \quad$ Struct. Eng., 1998; 124 (7): 798-808.

446 [24] Chung KF, Ip KH. Finite element investigation on the structural behaviour of cold447 formed steel bolted connections, Eng. Struct., 2002; 1115-1125.

448 [25] Chung KF, Ip KH. Finite element modelling of bolted connections between cold-formed $449 \quad$ steel strips and hot-rolled steel plates under static shear loading, Eng. Struct., 2000; $450 \quad 1271-1284$.

451

452

453

454

455

456

457

458

[26] Clarke MJ. ColdSteel/4600 Version 2.15, Dematic Pty Ltd, Belrose, NSW, Australia, 2009.

[27] Teh LH, Clements DDA. Block shear capacity of bolted connections in cold-reduced steel sheets, J. Struct. Eng., 2012; 138 (4): 459-467.

[28] Clements DDA, Teh LH. Active shear planes of bolted connections failing in block shear, J. Struct. Eng., 2013; 139 (3), 320-327.

[29] Rogers CA, Hancock GJ. Failure modes of bolted sheet steel connections loaded in shear, J. Struct. Eng., 2000; 126 (3): 288-296. 
459 [30] AISI. North American Specification for the Design of Cold-formed Steel Structural 460 Members 2007 Edition, American Iron and Steel Institute, 2007.

\section{Notation}

$462 A_{\mathrm{n}}=$ net area of considered section

$463 \quad c=$ test net section efficiency factor

$464 C_{\mathrm{p}}=$ correction factor

$465 C_{\phi}=$ calibration coefficient

$466 d=$ bolt diameter

$467 \quad F_{\mathrm{m}}=$ mean value of fabrication factor

$468 \quad F_{\mathrm{u}}=$ tensile strength of steel material

$469 \quad F_{\mathrm{y}}=$ yield stress of steel material

$470 \quad k_{\mathrm{t}}=$ net section efficiency factor according to AS/NZS 4600:2005

$471 L=$ connection length

$472 M_{\mathrm{m}}=$ mean value of material factor

$473 \quad P_{\mathrm{m}}=$ mean value of professional factor

$474 \quad P_{\mathrm{p}}=$ predicted failure load

$475 \quad t=$ nominal sheet thickness

$476 \quad t_{\text {base }}=$ base metal thickness

$477 \quad V_{\mathrm{F}}=$ coefficient of variation of fabrication factor

$478 V_{\mathrm{M}}=$ coefficient of variation of material factor

$479 V_{\mathrm{P}}=$ coefficient of variation of professional factor

$480 \quad V_{\mathrm{Q}}=$ coefficient of variation of load effects

$481 W_{\mathrm{c}}=$ web depth

$482 W_{\mathrm{f}}=$ flange width

$483 \bar{x}=$ connection eccentricity 
$484 \beta_{0}=$ target reliability index

$485 \varepsilon_{15}=$ elongation at fracture over a gauge length of $15 \mathrm{~mm}$

$486 \varepsilon_{25}=$ elongation at fracture over a gauge length of $25 \mathrm{~mm}$

$487 \varepsilon_{50}=$ elongation at fracture over a gauge length of $50 \mathrm{~mm}$

$488 \varepsilon_{\mathrm{uo}}=$ uniform elongation outside fracture zone

$489 \phi=$ resistance factor (or capacity reduction factor) 

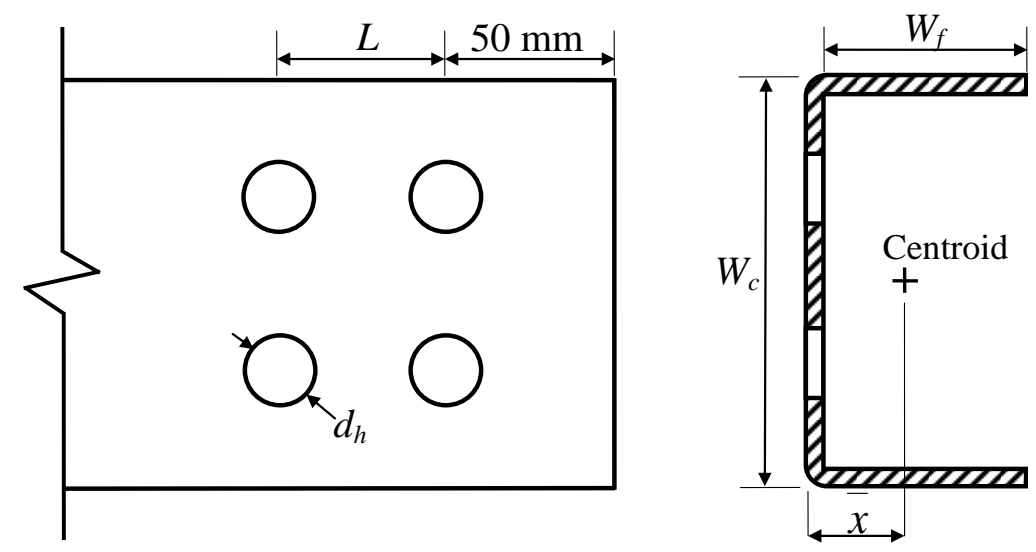

Figure 1 Geometric dimensions of a channel member bolted at the web 


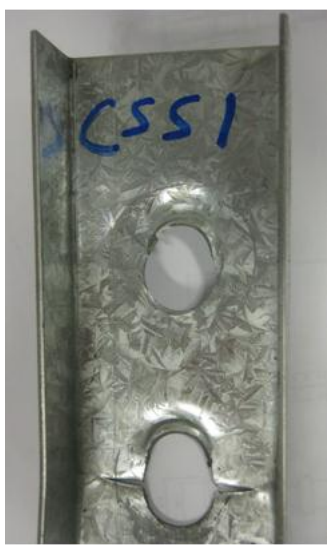

(a) $1.5 \mathrm{~mm}$ CSS specimen

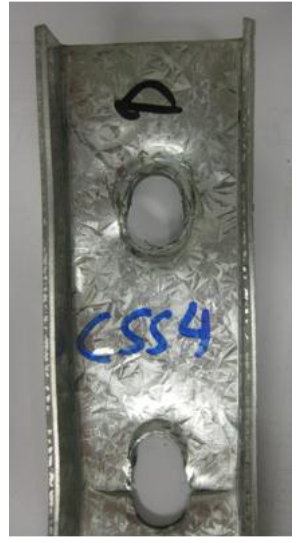

(b) $3.0 \mathrm{~mm}$ CSS specimen

Figure 2 Specimens with a single line of bolts in the axial direction 

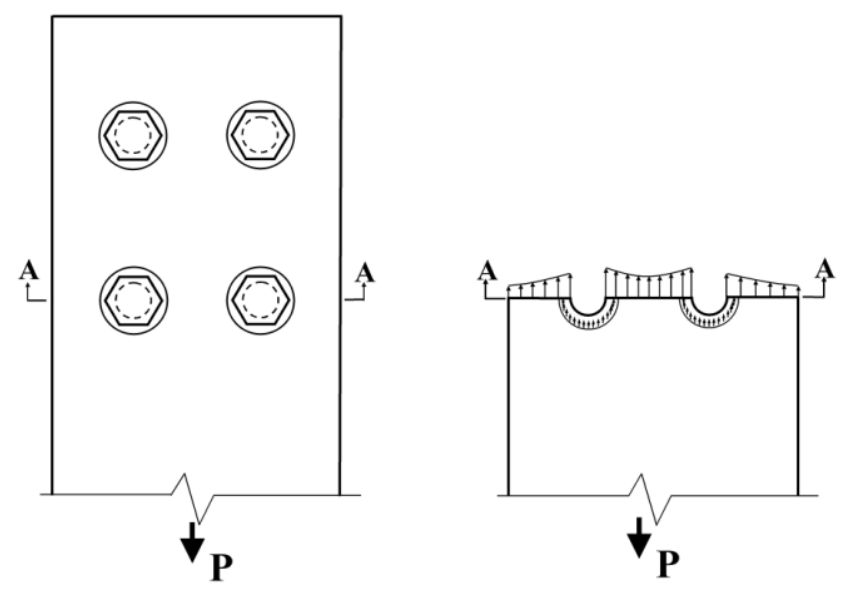

Figure 3 Contribution of bolt friction to tension capacity 


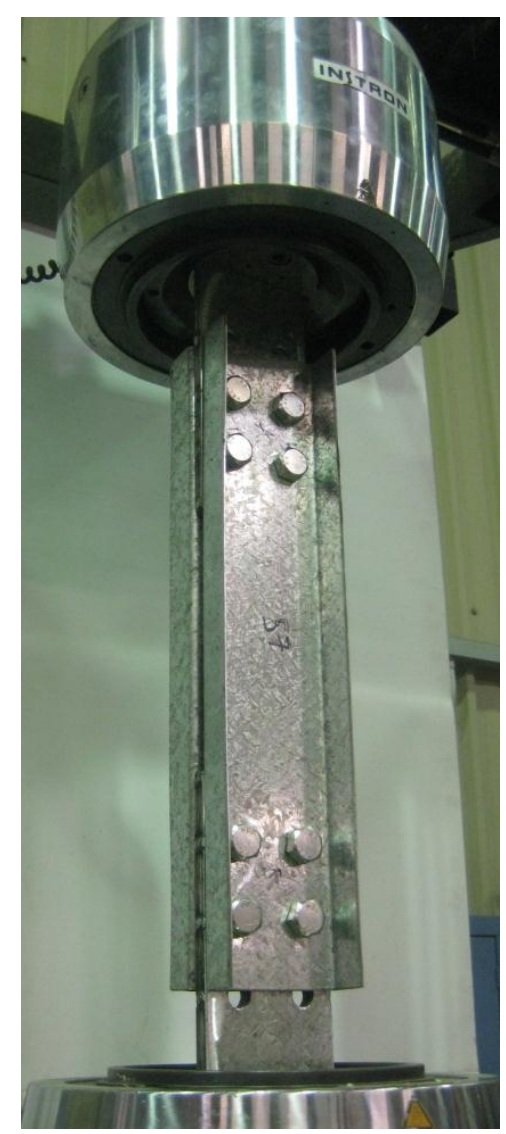

Figure 4 Tension test arrangement (back-to-back specimen) 


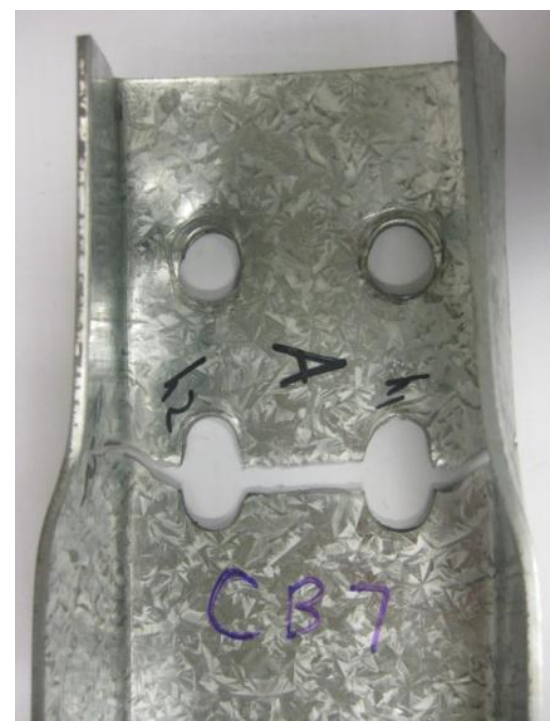

Figure 5 Net section fracture of one half of a back-to-back channel specimen 


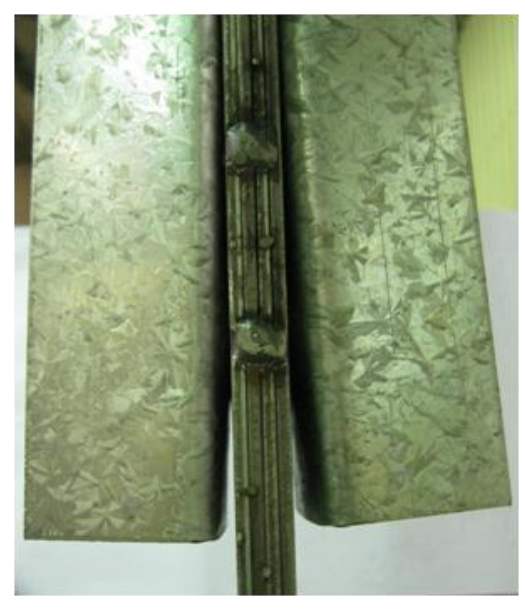

(a) Local bending

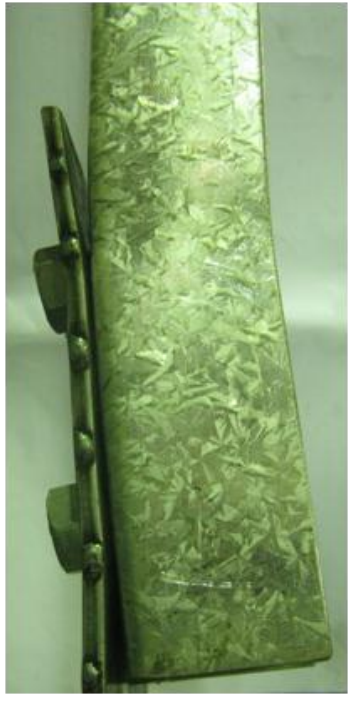

(b) Global bending

Figure 6 Local (CB12) and global bending of channel braces 


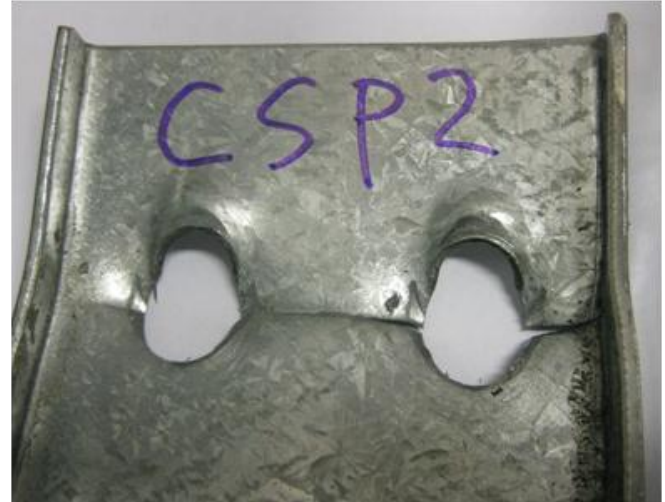

(a) Net section fracture

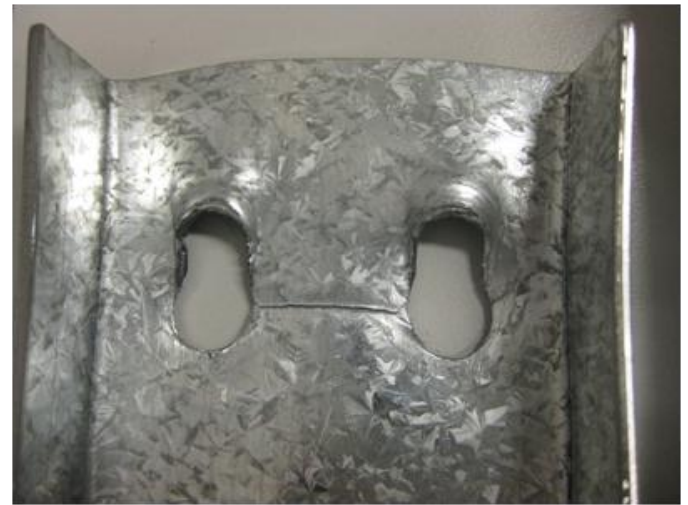

(b) Block shear failure

Figure 7 Net section fracture and block shear failure 
Table 1 Average material properties

\begin{tabular}{ccccccccc}
\hline & $\boldsymbol{t}_{\text {base }}$ & $\boldsymbol{F}_{\mathbf{y}}$ & $\boldsymbol{F}_{\mathbf{u}}$ & $\boldsymbol{F}_{\mathbf{u}} / \boldsymbol{F}_{\mathbf{y}}$ & $\boldsymbol{\varepsilon}_{15}$ & $\boldsymbol{\varepsilon}_{\mathbf{2 5}}$ & $\boldsymbol{\varepsilon}_{\mathbf{5 0}}$ & $\boldsymbol{\varepsilon}_{\mathrm{uo}}$ \\
& $(\mathbf{m m})$ & $(\mathbf{M P a})$ & $(\mathbf{M P a})$ & & $(\boldsymbol{\%})$ & $(\boldsymbol{\%})$ & $(\boldsymbol{\%})$ & $(\boldsymbol{\%})$ \\
\hline $1.5 \mathrm{~mm}$ & 1.48 & 605 & 630 & 1.04 & 21.3 & 18.0 & 12.0 & 6.8 \\
& & & & & & & & \\
$3.0 \mathrm{~mm}$ & 2.95 & 530 & 580 & 1.09 & 29.3 & 22.0 & 15.3 & 8.1 \\
\hline
\end{tabular}


Table 2 Results of double channel bolted back-to-back specimens $(t=3.0 \mathrm{~mm})$

\begin{tabular}{|c|c|c|c|c|c|c|c|c|c|c|c|c|}
\hline \multirow{2}{*}{ Spec } & \multirow{2}{*}{$\begin{array}{c}d_{\mathrm{h}} \\
(\mathbf{m m})\end{array}$} & \multirow{2}{*}{$\begin{array}{c}W_{\mathbf{c}} \\
(\mathbf{m m})\end{array}$} & \multirow{2}{*}{$\begin{array}{c}W_{\mathbf{f}} \\
(\mathbf{m m})\end{array}$} & \multirow{2}{*}{$\begin{array}{c}\bar{x} \\
(\mathbf{m m})\end{array}$} & \multirow{2}{*}{$\begin{array}{c}L \\
(\mathbf{m m})\end{array}$} & \multirow{2}{*}{$\begin{array}{c}A_{n} \\
\left(\mathbf{m m}^{2}\right)\end{array}$} & \multirow{2}{*}{$c$} & \multicolumn{5}{|c|}{$P_{\mathrm{t}} / \boldsymbol{P}_{\mathrm{p}}$} \\
\hline & & & & & & & & (2) & (4) & (5) & (6) & (7) \\
\hline CB1 & 17 & 100 & 30 & 6.90 & 50 & 779 & 0.74 & 0.74 & 0.83 & 0.86 & 1.06 & 0.96 \\
\hline CB2 & & & & & 75 & 791 & 0.85 & 0.85 & 0.94 & 0.93 & 1.17 & 1.09 \\
\hline CB3 & & & & & 100 & 774 & 0.89 & 0.89 & 0.99 & 0.95 & 1.20 & 1.14 \\
\hline CB4 & & & 40 & 10.2 & 50 & 898 & 0.69 & 0.69 & 0.76 & 0.86 & 1.05 & 0.91 \\
\hline CB5 & & & & & 75 & 893 & 0.76 & 0.76 & 0.85 & 0.88 & 1.11 & 1.00 \\
\hline CB6 & & & & & 100 & 904 & 0.82 & 0.82 & 0.91 & 0.91 & 1.16 & 1.08 \\
\hline CB7 & & & 50 & 13.9 & 50 & 1017 & 0.65 & 0.65 & 0.72 & 0.90 & 1.05 & 0.87 \\
\hline CB8 & & & & & 75 & 1024 & 0.68 & 0.68 & 0.76 & 0.84 & 1.05 & 0.92 \\
\hline CB9 & & & & & 100 & 1011 & 0.73 & 0.73 & 0.81 & 0.85 & 1.09 & 0.98 \\
\hline CB10 & 13 & 80 & 40 & 11.4 & 40 & 832 & 0.65 & 0.65 & 0.73 & 0.91 & 1.06 & 0.88 \\
\hline CB11 & & & & & 60 & 827 & 0.69 & 0.69 & 0.77 & 0.85 & 1.06 & 0.93 \\
\hline CB12* & & & & & 80 & 831 & 0.77 & 0.77 & 0.85 & 0.89 & 1.14 & 1.03 \\
\hline CB13 & 17 & 120 & & 9.30 & 50 & 1008 & 0.70 & 0.70 & 0.78 & 0.87 & 1.04 & 0.91 \\
\hline CB14 & & & & & 75 & 1017 & 0.72 & 0.72 & 0.80 & 0.82 & 1.03 & 0.94 \\
\hline \multirow[t]{3}{*}{ CB15 } & & & & & 100 & 1016 & 0.79 & 0.79 & 0.87 & 0.87 & 1.09 & 1.02 \\
\hline & & & & & & & Mean & 0.74 & 0.82 & 0.88 & 1.09 & 0.98 \\
\hline & & & & & & & $\mathrm{COV}$ & 0.095 & 0.094 & 0.041 & 0.049 & 0.084 \\
\hline
\end{tabular}

*Three rows of bolts were used to prevent bolt failure. 
Table 3 Results of single channel specimens with a single axial line of bolts ( $d_{\mathrm{h}}=17 \mathrm{~mm}$ )

\begin{tabular}{|c|c|c|c|c|c|c|c|c|c|c|c|}
\hline \multirow{2}{*}{ Spec } & \multirow{2}{*}{$\begin{array}{c}W_{\mathbf{c}} \\
(\mathbf{m m})\end{array}$} & \multirow{2}{*}{$\begin{array}{c}W_{\mathbf{f}} \\
(\mathbf{m m})\end{array}$} & \multirow{2}{*}{$\begin{array}{c}t \\
(\mathbf{m m})\end{array}$} & \multirow{2}{*}{$\begin{array}{c}\bar{x} \\
(\mathbf{m m})\end{array}$} & \multirow{2}{*}{$\begin{array}{c}L \\
(\mathrm{~mm})\end{array}$} & \multirow{2}{*}{$\begin{array}{c}A_{n} \\
\left(\mathbf{m m}^{2}\right)\end{array}$} & \multirow{2}{*}{$c$} & \multicolumn{4}{|c|}{$P_{\mathrm{t}} / P_{\mathrm{p}}$} \\
\hline & & & & & & & & (3) & (4) & (5) & (6) \\
\hline CSS1 & 50 & 20 & 1.5 & 5.13 & 50 & 112 & 0.67 & 0.79 & 0.74 & 0.74 & 0.95 \\
\hline CSS2 & & & 3.0 & 5.76 & & 232 & 0.74 & 0.87 & 0.82 & 0.84 & 1.06 \\
\hline CSS3 & & & 1.5 & 5.13 & 75 & 112 & 0.78 & 0.91 & 0.86 & 0.83 & 1.08 \\
\hline CSS4 & & & 3.0 & 5.76 & & 228 & 0.85 & 1.00 & 0.95 & 0.92 & 1.18 \\
\hline CSS5 & & & 1.5 & 5.13 & 100 & 111 & 0.79 & 0.92 & 0.87 & 0.83 & 1.07 \\
\hline CSS6 & & & 3.0 & 5.76 & & 233 & 0.87 & 1.02 & 0.96 & 0.92 & 1.19 \\
\hline CSS7 & & 30 & 1.5 & 8.92 & 50 & 141 & 0.63 & 0.74 & 0.70 & 0.76 & 0.96 \\
\hline CSS8 & & & 3.0 & 9.60 & & 291 & 0.61 & 0.72 & 0.68 & 0.76 & 0.95 \\
\hline CSS9 & & & 1.5 & 8.92 & 75 & 142 & 0.67 & 0.79 & 0.75 & 0.76 & 1.00 \\
\hline CSS10 & & & 3.0 & 9.60 & & 291 & 0.69 & 0.82 & 0.77 & 0.79 & 1.02 \\
\hline CSS11 & & & 1.5 & 8.92 & 100 & 144 & 0.65 & 0.76 & 0.72 & 0.71 & 0.95 \\
\hline \multirow[t]{3}{*}{ CSS12 } & & & 3.0 & 9.60 & & 292 & 0.75 & 0.88 & 0.83 & 0.82 & 1.08 \\
\hline & & & & & & & Mean & 0.85 & 0.80 & 0.81 & 1.04 \\
\hline & & & & & & & cov & 0.117 & 0.117 & 0.082 & 0.081 \\
\hline
\end{tabular}


Table 4 Results of single channel specimens with the rectangular bolting pattern [5]

\begin{tabular}{|c|c|c|c|c|c|c|c|c|c|c|c|c|}
\hline \multirow{2}{*}{ Spec } & \multirow{2}{*}{$\begin{array}{c}d_{\mathrm{h}} \\
(\mathbf{m m})\end{array}$} & \multirow{2}{*}{$\begin{array}{c}W_{\mathrm{c}} \\
(\mathbf{m m})\end{array}$} & \multirow{2}{*}{$\begin{array}{c}W_{\mathrm{f}} \\
(\mathbf{m m})\end{array}$} & \multirow{2}{*}{$\begin{array}{c}t \\
(\mathbf{m m})\end{array}$} & \multirow{2}{*}{$\begin{array}{c}\bar{x} \\
(\mathbf{m m})\end{array}$} & \multirow{2}{*}{$\begin{array}{c}L \\
(\mathbf{m m})\end{array}$} & \multirow{2}{*}{$\begin{array}{c}A_{n} \\
\left(\mathbf{m m}^{2}\right)\end{array}$} & \multirow{2}{*}{$c$} & \multicolumn{4}{|c|}{$\boldsymbol{P}_{\mathrm{t}} / \boldsymbol{P}_{\mathrm{p}}$} \\
\hline & & & & & & & & & (3) & (4) & (5) & (6) \\
\hline $\mathrm{CH} 1$ & 17 & 100 & 30 & 1.5 & 6.28 & 50 & 190 & 0.67 & 0.79 & 0.75 & 0.77 & 0.95 \\
\hline $\mathrm{CH} 2$ & & & & 3.0 & 6.90 & & 381 & 0.73 & 0.86 & 0.81 & 0.85 & 1.04 \\
\hline $\mathrm{CH} 3$ & & & & 1.5 & 6.28 & 75 & 185 & 0.72 & 0.85 & 0.80 & 0.79 & 0.99 \\
\hline $\mathrm{CH} 4$ & & & & 3.0 & 6.90 & & 386 & 0.78 & 0.91 & 0.86 & 0.85 & 1.07 \\
\hline $\mathrm{CH} 5$ & & & & 1.5 & 6.28 & 100 & 188 & 0.74 & 0.88 & 0.83 & 0.79 & 1.00 \\
\hline CH6 & & & & 3.0 & 6.90 & & 389 & 0.79 & 0.93 & 0.88 & 0.85 & 1.07 \\
\hline $\mathrm{CH} 7$ & & & 40 & 1.5 & 9.56 & 50 & 220 & 0.61 & 0.72 & 0.68 & 0.76 & 0.93 \\
\hline $\mathrm{CH} 8$ & & & & 3.0 & 10.2 & & 449 & 0.64 & 0.76 & 0.71 & 0.81 & 0.98 \\
\hline CH8_2 & & & & & & & 449 & 0.66 & 0.78 & 0.74 & 0.83 & 1.01 \\
\hline $\mathrm{CH} 10$ & & & & & & 75 & 450 & 0.69 & 0.81 & 0.76 & 0.79 & 1.00 \\
\hline CH10_2 & & & & & & & 449 & 0.66 & 0.77 & 0.73 & 0.76 & 0.96 \\
\hline CH11 & & & & 1.5 & 9.56 & 100 & 217 & 0.67 & 0.79 & 0.75 & 0.75 & 0.95 \\
\hline $\mathrm{CH} 12$ & & & & 3.0 & 10.2 & & 450 & 0.70 & 0.83 & 0.78 & 0.78 & 1.00 \\
\hline CH12_2 & & & & & & & 451 & 0.71 & 0.83 & 0.79 & 0.79 & 1.01 \\
\hline CH13 & & & 50 & 1.5 & 13.2 & 50 & 248 & 0.59 & 0.69 & 0.65 & 0.79 & 0.95 \\
\hline CH14 & & & & 3.0 & 13.9 & & 502 & 0.61 & 0.71 & 0.67 & 0.83 & 0.98 \\
\hline CH15 & & & & 1.5 & 13.2 & 75 & 248 & 0.62 & 0.72 & 0.68 & 0.75 & 0.94 \\
\hline CH16 & & & & 3.0 & 13.9 & & 507 & 0.64 & 0.76 & 0.71 & 0.78 & 0.98 \\
\hline CH17 & & & & 1.5 & 13.2 & 100 & 246 & 0.63 & 0.74 & 0.70 & 0.73 & 0.94 \\
\hline CH18 & & & & 3.0 & 13.9 & & 501 & 0.64 & 0.76 & 0.71 & 0.75 & 0.96 \\
\hline CH19 & 13 & 80 & 40 & & 11.4 & 40 & 408 & 0.62 & 0.73 & 0.69 & 0.87 & 1.02 \\
\hline CH2O & & & & & & 60 & 392 & 0.65 & 0.76 & 0.72 & 0.80 & 0.99 \\
\hline CH21 & & & & & & 80 & 407 & 0.66 & 0.77 & 0.73 & 0.77 & 0.98 \\
\hline $\mathrm{CH} 22$ & & & 20 & & 4.60 & 40 & 290 & 0.76 & 0.89 & 0.84 & 0.86 & 1.05 \\
\hline $\mathrm{CH} 23$ & & & & & & 60 & 287 & 0.82 & 0.96 & 0.91 & 0.89 & 1.10 \\
\hline $\mathrm{CH} 24$ & & & & & & 80 & 294 & 0.86 & 1.01 & 0.95 & 0.91 & 1.13 \\
\hline $\mathrm{CH} 25$ & 17 & 120 & 40 & & 9.30 & 50 & 506 & 0.71 & 0.84 & 0.79 & 0.87 & 1.06 \\
\hline $\mathrm{CH} 26$ & & & & & & 75 & 500 & 0.73 & 0.86 & 0.81 & 0.83 & 1.04 \\
\hline $\mathrm{CH} 27$ & & & & & & 100 & 502 & 0.75 & 0.88 & 0.83 & 0.82 & 1.04 \\
\hline & & & & & & & & Mean & 0.81 & 0.77 & 0.81 & 1.00 \\
\hline & & & & & & & & $\mathrm{COV}$ & 0.097 & 0.097 & 0.059 & 0.051 \\
\hline
\end{tabular}


Table 5 Results of single channel specimens with a single row of bolts $\left(d_{\mathrm{h}}=17 \mathrm{~mm}\right)$

\begin{tabular}{|c|c|c|c|c|c|c|c|c|}
\hline \multirow{2}{*}{ Spec } & \multirow{2}{*}{$\begin{array}{c}W_{\mathbf{c}} \\
(\mathbf{m m})\end{array}$} & \multirow{2}{*}{$\begin{array}{c}W_{\mathbf{f}} \\
(\mathbf{m m})\end{array}$} & \multirow{2}{*}{$\begin{array}{c}t \\
(\mathbf{m m})\end{array}$} & \multirow{2}{*}{$\begin{array}{c}\bar{x} \\
(\mathbf{m m})\end{array}$} & \multirow{2}{*}{$\begin{array}{c}A_{n} \\
\left(\mathbf{m m}^{2}\right)\end{array}$} & \multirow{2}{*}{$c$} & \multicolumn{2}{|c|}{$P_{\mathrm{t}} / P_{\mathrm{p}}$} \\
\hline & & & & & & & (3) & (7) \\
\hline CSP1 & 100 & 10 & 1.5 & 1.50 & 125 & 0.839 & 0.988 & 0.988 \\
\hline \multirow[t]{3}{*}{ CSP2 } & & & 3.0 & 2.17 & 259 & 0.838 & 0.986 & 0.990 \\
\hline & & & & & & Mean & 0.987 & 0.989 \\
\hline & & & & & & cov & 0.002 & 0.002 \\
\hline
\end{tabular}


Table 6 Results of Group A specimens tested by Pan [10] $\left(t=2.4 \mathrm{~mm}, d_{\mathrm{h}}=14.3 \mathrm{~mm}, L=40\right.$ $\mathrm{mm}$ )

\begin{tabular}{cccccccccc}
\hline \multirow{2}{*}{$\begin{array}{c}\boldsymbol{W}_{\mathbf{c}} \\
(\mathbf{m m})\end{array}$} & $\begin{array}{c}\boldsymbol{W}_{\mathbf{f}} \\
(\mathbf{m m})\end{array}$ & $\begin{array}{c}\boldsymbol{W}_{\mathbf{T}} \\
(\mathbf{m m})\end{array}$ & $\begin{array}{c}\bar{x} \\
(\mathbf{m m})\end{array}$ & $\boldsymbol{c}$ & \multicolumn{5}{c}{$\boldsymbol{P}_{\mathbf{t}} / \boldsymbol{P}_{\mathbf{p}}$} \\
\cline { 6 - 9 } & & & & $\mathbf{( 3 )}$ & $\mathbf{( 4 )}$ & $(\mathbf{5})$ & $(\mathbf{6})$ \\
\hline 80 & 60 & 200 & 19.2 & 0.53 & 0.63 & 0.65 & 1.03 & 1.00 \\
& 50 & 180 & 15.0 & 0.58 & 0.68 & 0.66 & 0.86 & 0.98 \\
& 40 & 160 & 11.1 & 0.65 & 0.76 & 0.72 & 0.90 & 1.05 \\
100 & & 180 & 9.96 & 0.58 & 0.69 & 0.65 & 0.78 & 0.92 \\
120 & & 200 & 9.05 & 0.53 & 0.62 & 0.59 & 0.68 & 0.81 \\
\hline
\end{tabular}

